\title{
Study on the Relationship of FDI and Processing Trade Value-added Rate-Based on the Data from Shandong Province of China
}

\author{
SUI Hongxia \\ Economics and Management College \\ Weifang University \\ Weifang, Shandong, China \\ e-mail:wfshxgjmy@163.com
}

\section{Keywords: FDI, Processing Trade,Value-added Rate}

\begin{abstract}
Based on the data of Shandong province in china over the 1998-2017 periods, this paper examines the impacts of inward FDI from Japan, Korea and USA on the Processing Trade Valueadded Rate (ADVA) respectively. The cointegration equation indicates Japanese and Korean direct investments in Shandong Province are positively correlated with ADVA, but American direct investment is negative. There is no evidence that the FDI from Japan, Korea and USA have effects on the processing trade value-added rate of Shandong province as they are not Granger causality of ADVA. The power to promote the transformation and upgrading of Shandong's processing trade comes from inside instead of outside, and independent technology innovation is critical.
\end{abstract}

\section{Introduction}

Since reform and opening up to the world, the scale of foreign direct investment (FDI) in China has increased tremendously and made great contributions to the development of processing trade. Facing fierce competition from other developing countries, with the increasing cost of labor plus environmental and resource restriction, Chinese government put forward the strategy of transformation and upgrading of processing trade in 2003 initiatively. Transformation refers to the transformation of processing trade development mode. Upgrading refers to the overall optimization of technological structure, organizational structure, industrial layout, and the structure of industrial sectors, etc..

Since 2003, lots of measures have been adopted to promote the strategy by central and local governments and significant achievements has made. Many scholars began to focus on the progress of transformation and upgrading of processing trade in China by applying some indexes. One important index is Processing trade value-added rate (VADA), which reflects not only the industrial chain's length about processing trade, but also the position and role of China in global division[1]. VADA is a comprehensive index which can also reflects the technology progress degree in processing trade.

This paper is going to explore the relationship between the value-added rate of processing trade and FDI. Instead of using the aggregate inward FDI from the world, this paper only use the FDI from Japan, Korea and USA respectively, the three major investing countries in China. The aim is to see whether the FDI has brought effect on the processing trade value-added rate. If it has, whether the effects brought by different country's FDI are different.

\section{2. literature review}

Many scholars has made research on processing trade. Egger.Hartmut, Egger.Peter(2005) assesses the determinants of European outward and inward processing trade and find that infrastructure variables, relative factor endowments and other cost variables are important determinants for the EU's outward processing trade. Costs also play a key role for the EU's inward processing trade[2].

QU Jian-zhong, WU Zong-jie (2013)sets up an index system to evaluate the performance of transformation and upgrading of processing trade, and uses Factor Analysis Method to empirically 
test the performance of transformation and upgrading of Shandong's processing trade. They got results that the performance of transformation and upgrading of Shandong's processing trade is generally on a slow upward trend, but there still exists some problems[3]

$\mathrm{Ru}$ Xiaoding(2007) analyzed the new characteristics of processing trade in China and found manufactured products of the country's processing trade are under changing from simple laborintensive products to hybrid of labor-intensive products mixed with capital and technological intensive products as a result of the spillover effect of transnational corporations in the country[4].

As a developed eastern province in China, Shandong's processing trade has occupied a great share in the whole country and got great achievement. So the data from Shandong province is representative. This paper will attempt to make an empirical study on the relationship between FDI from three major countries, Japan, Korea and USA and the processing trade value-added rate based on the data of Shandong Province.

\section{Data choose}

The standard time series during 1998-2017 of Shandong Province of China about Foreign Real Investment from Japan(JAP), Korea(KOR) and USA(USA) have been used. The original import and export values of processing trade are used to calculate the Value-added Rate Processing Trade (ADVA) with the formulation: ADVA=(Export-Import)/Import. And it is found the ADVA is under fluctuant increasing since 2003. All original data comes from Shandong Provincial Bureau of Statistics net and Department of Commerce of Shandong Province net .

As the natural logarithm transform on variables can eliminate heteroscedasticity likely existed without affecting the relationship between variables, the logarithmic transformation of the initial variables will be applied to this analysis. Finally, we get the time series LNADVA, LNJAP, LNKOR and LNUSA donating Processing Trade Value-added Rate, the FDI from Japan, the FDI from Korea and the FDI from USA respectively. The software Eviews6.0 is applied in this analysis.

\section{Co-integration test of variables and Granger Causality Test}

\subsection{Unit Root Test}

Augmented Dickey-Fuller Unit Root Test method is commonly used before cointegration test in order to avoid spurious regression in the analysis of non-stationary time series. The result is shown in Table1.

Table1: Augmented Dickey-Fuller Unit Root Test Result (ADF test)

\begin{tabular}{c|c|c|c|c|c}
\hline Variables & $\begin{array}{c}\text { Test Type } \\
(\mathrm{C}, \mathrm{T}, \mathrm{K})\end{array}$ & $\begin{array}{c}\text { ADF Test } \\
\text { Statistic }\end{array}$ & $\begin{array}{c}5 \% \text { Critical } \\
\text { Value }\end{array}$ & $\begin{array}{c}10 \% \\
\text { Critical } \\
\text { Value }\end{array}$ & P-value \\
\hline LNADVA & $(\mathrm{C}, \mathrm{T}, 0)$ & -2.694312 & -3.6736 & -3.2774 & $0.2490^{*}$ \\
\hline LNJAP & $(\mathrm{C}, 0,1)$ & -3.221951 & -3.0404 & -2.6606 & $0.0354^{* *}$ \\
\hline LNKOR & $(\mathrm{C}, \mathrm{T}, 4)$ & -3.985021 & -3.7597 & -3.3249 & $0.0345^{* *}$ \\
\hline LNUSA & $(\mathrm{C}, 0,0)$ & -3.552611 & -3.0299 & -2.6552 & $0.0178^{* *}$ \\
\hline DLNADVA & $(\mathrm{C}, \mathrm{T}, 0)$ & -4.173978 & -3.6908 & -3.2869 & $0.0209^{* *}$ \\
\hline
\end{tabular}

Note: $\mathrm{C}, \mathrm{T}$ and $\mathrm{K}$ in test type $(\mathrm{C}, \mathrm{T}, \mathrm{K})$ denotes intercept, trend and the lagged difference included in the test equation respectively. $*$ donates the null hypothesis of a unit root is accepted at the $5 \%$ significance level, the time series is not stationary. **donates the time series is stationary.

From the results in Table1: at 5\% significance level, the ADF Test Statistics at level of time series LNJAP, LNKOR and LNUSA are lower than their critical values, so all of the three time series are stationary I (0) process. At 5\% significance level, LNADVA is not stationary, but the first-order difference of LNADVA is stationary. So LNADVA is stationary I (1) process. DLNADVA stands for first-order difference of LNADVA, then DLNADVA is stationary I (0) process, too. So, all of the four time series DLNADVA, LNJAP, LNKOR AND LNUSA are the same stationary I $(0)$ process. 


\subsection{Co-integration test of variables}

The co-integration theory was commonly applied to analyze the long-term stable relationship among variables of time series which are the same stationary process. For two variables, E-G test is commonly used, but for three variables or more, Johansen cointegration test should be applied based on the VAR model.

\subsubsection{Estimate VAR}

As the Johansen cointegration test is sensitive to the lag order number, so the VAR model is estimated to determine the optimal lag order number. The results of the analysis are shown in Table2. According to the LR statistic, FPE, AIC and SC information criteria, the optimal lag order number is 0 .

Table2: VAR Lag Order Selection Criteria

\begin{tabular}{c|c|c|c|c|c}
\hline Lag & $\log \mathrm{L}$ & LR & FPE & AIC & SC \\
\hline 0 & 10.14853 & NA* $^{*}$ & $5.70 \mathrm{e}-06^{*}$ & $-0.723356^{*}$ & $-0.527306^{*}$ \\
\hline 1 & 25.77274 & 22.05771 & $6.40 \mathrm{e}-06$ & -0.679146 & 0.301105 \\
\hline 2 & 35.63720 & 9.284200 & $1.98 \mathrm{e}-05$ & 0.042682 & 1.807134 \\
\hline
\end{tabular}

Notes: * indicates lag order selected by the criterion

\subsubsection{Co-integration test of variables}

The Johansen test method (Johansen 1988; Johansen and Juselius 1990) is applied to carry out the cointegration test, and results are shown in table3. Trace test indicates 4 cointegrating equations at the $5 \%$ level. In other words, there is long-term stable equilibrium relationship among the variables. The cointegrating equation under Max-Eigenvalue is as the following:

DADVALUE=0.016396LNJAP+0.131147LNKOR-0.218866LNUSA

The adjustment coefficients are $-0.136357,-0.168961,0.685072$, and -6.120157 respectively, which meet the requirement that at least one coefficient is negative. So the cointegrating equation is effective. The positive coefficients of LNJAP and LNKOR in the equation indicate that inward FDI from Japan and Korea to Shandong province has done positive contribution to the processing trade value-added rate. But the negative coefficient of LNUSA indicates FDI from America decreased the processing trade value-added rate.

Table3: Cointegration Rank Test (Trace)

\begin{tabular}{c|c|c|c|c}
\hline $\begin{array}{c}\text { Hypothesized No. of } \\
\text { CE(s) }\end{array}$ & Eigenvalue & $\begin{array}{c}\text { Trace } \\
\text { Statistic }\end{array}$ & 0.05 Critical Value & P ob. $* *$ \\
\hline None $*$ & 0.759670 & 60.45419 & 47.85613 & 0.0021 \\
\hline At most $1 *$ & 0.587936 & 34.79081 & 29.79707 & 0.0122 \\
\hline At most $2 *$ & 0.537258 & 18.83244 & 15.49471 & 0.0151 \\
\hline At most $3 *$ & 0.240930 & 4.961911 & 3.841466 & 0.0259 \\
\hline
\end{tabular}

Notes: Trace test indicates 4 cointegrating eqn(s) at the 0.05 level. $*$ denotes rejection of the hypothesis at the 0.05 level. **MacKinnon-Haug-Michelis (1999) p-values.

\subsection{Granger Causality Tests}

Granger causality test method is used to test the causal relationship between variables. In order to know whether the lags of one variable contribute to the better forecasting of another variable, the Granger causality test is run and results are shown in table4.

According to the Granger causality test results in table4, all of the null hypothesis are rejected at the 5\% level of significance. This finding suggests that LNJAP, LNKOR and LNUSA are not Granger Cause of DLNADVA. 
Table 4: Pairwise Granger Causality Tests

\begin{tabular}{l|c|c|c}
\hline \multicolumn{1}{c|}{ Null Hypothesis: } & Obs & F-Statistic & Probability \\
\hline JAPAN does not Granger Cause DADVALUE & 18 & 0.51439 & 0.4843 \\
DADVALUE does not Granger Cause JAPAN & 18 & 0.01892 & 0.8924 \\
KOREA does not Granger Cause DADVALUE & 18 & 1.55416 & 0.2316 \\
DADVALUE does not Granger Cause KORE & 18 & 0.32684 & 0.5760 \\
USA does not Granger Cause DADVALUE & 18 & 0.41405 & 0.5296 \\
DADVALUE does not Granger Cause USA & 18 & 0.02794 & 0.8695 \\
\hline
\end{tabular}

\section{Conclusion and suggestion}

Based on the data of Shandong province in china over 1998-2017 periods, this paper examines the impacts of inward FDI from Japan, Korea and USA on the processing trade value-added rate respectively. The cointegration equation indicates Japanese and Korean direct investments in Shandong Province are positively correlated with the processing trade value-added rate, but American direct investment is negative. There is no evidence that the FDI from Japan, Korea and USA have effects on the processing trade value-added rate of Shandong province as they are not Granger causality of the processing trade value-added rate. Such result indicates that the force to promote the processing trade value-added rate comes from inside instead of outside.

Comply with the requirements from the central government, Shandong government has adopted powerful measurements to promote the transformation and upgrading of processing trade since 2003. But, due to the slow economy development, trade protectionism has emerged in worldwide. China's industrial development is under the pressure posed by the trend of reindustrialization in developed countries and homogenous competition among emerging economies[5]. Under present complicated international trade and investment circumstances, Chinese enterprises should know the more development, the difficult to get high technology from other countries. Just as China' president $\mathrm{Xi}$ said recently, "The key core technology can't be got through buying, asking or begging". The only way to keep continuous development is to try to get rid of reliance on the outside technology through innovation. China should strengthen investment in R\&D, promote labor quality and technological progress of processing trade enterprises, and enhance the ability to innovate to keep the processing Trade continues to develop.

\section{References}

[1] ZHANG Ming, HU Bing. An empirical study on processing trade appreciation rate, the Journal of International Trade issues, Apr.2010, Vol.4, p25-31.

[2] Egger.Hartmut, Egger.Peter, The Determinants of EU Processing Trade, World Economy. Feb2005, Vol. 28 Issue 2, p147-168. 22p.

[3] QU Jian-zhong, WU Zong-jie, Quantitative Evaluation on the Performance of Transformation and Upgrading of Shandong's Processing Trade. East China Economic Management. Nov.2013, Vol.27,No.11.

[4] $\mathrm{Ru}$ Xiaoding, The Characteristics and Trend of China's Processing Trade Development in Recent Years. Journal of Chinese Economy. Jul2007, Vol. 40 Issue 4, p70-78. 9p.

[5] Miao Wei, Accelerating the Transformation and Upgrading of Industries, English Edition of Qiushi Journal, Vol.4 No.2 April1, 2012. 